\title{
THE COMPREHENSION OF CHEMISTRY TEACHER TOWARD STEM INTEGRATION IN CHEMISTRY LEARNING
}

\author{
Hafsah Thaha ${ }^{1}$, Nur Fitriyana ${ }^{2}$, and Fapriyan M. W. ${ }^{3}$ \\ ${ }^{1}$ Faculty of Science and Mathematics Universiti Pendidikan Sultan Idris, Malaysia \\ ${ }^{2}$ Faculty of Mathematics and Natural Sciences Universitas Negeri Yogyakarta, Indonesia \\ ${ }^{3}$ Magister of Chemistry Education Study Program Universitas Negeri Yogyakarta, Indonesia \\ email: nur.fitriyana@uny.ac.id
}

\begin{abstract}
This study was aimed to investigate the chemistry teacher knowledge related STEM integration in chemistry learning at automotive engineering programme of vocational school This research belonged to descriptive study with survey methods. The samples consisted of 19 ChTAE at automotive vocational school in Bantul Regency, Indonesia that were established through saturated sampling technique. The preceding knowledge about the IC-STEM learning integration of ChTAE were achieved by using STEM Knowledge Questionnaire (STEM-KQ) consisting of 9 opened questions. The responses of ChTAE toward STEM-KQ were analysed using question-by-question with interpretative coding of content analysis. The results of this research indicate that the ChTAE have good knowledge in defining and explaining STEM which in line with chemistry subject. However, their skills in designing and implementing CI-STEM still need to be enhanced. As the matter of that, the ChTAE must follow the activities relating with the preparation of CI-STEM. Therefore, the ChTAE could implement a meaningful chemistry subject in line with automotive expertise programme at vocational school.
\end{abstract}

Keywords: STEM, vocational school, automotive engineering, chemistry

\section{INTRODUCTION}

STEM learning has been developed and used for some countries to encourage students in dealing with science, technology, engineering, and mathematics in a subject (Charismiadji, 2015). Integrated STEM approach could enhance the learning material as in the vocational material especially that dealing with daily basis activities (Banks \& Barlex, 2014). Thus, it could promote the relevant of the content knowledge with everyday lives such in chemistry subject. The relevant of chemistry content knowledge with daily lives is important in order to increase students' interest in studying chemistry (Liu et al., 2014; Shahali et al., 2016; Susanti et al., 2018; Wiyarsi et al., 2020). Not only enhancing students' interest, the use of CI-STEM could elevate students' creativity, knowledge, motivation, career, and confident (Lou et al., 2017; Liu et al., 2014; Shahali et al., 2016). Wang et al. (2011) stated that the use of integrated STEM approach could improve students' engagement in the learning activities in mathematics and sciences subject. Therefore, the CI-STEM could improve the students' visualization and outcomes on chemistry subject as another advantage in integrating STEM learning (Hinze et al., 2013; Susanti et al., 2018).

Another benefit in using CI-STEM according to Banks and Barlex (2014) are to achieve the curriculum remedy in STEM subject, to receive assistance in doing the research related with STEM, to enhance students' literacy and awareness to get a 
job, and to enhance students' motivation in working. National Research Council (2011) stated that STEM approach has its goal to multiply the learners who have STEM capability and also broadening the women participation in the workforce. It also enhances STEM literation for all of the learners including the student who don't want in the STEM related career. Unfortunately, the implementation of CISTEM is rarely experienced especially at the vocational school.

Concerning the vocational education in Indonesia, it aims to produce skill full students who have ability in following the need of the industries. Pilz et al. (2012) stated that vocational education is used to prepare the students in entering the working field after they are graduated. Therefore, the vocational education should have to synchronize the chemistry teaching materials with the working industries and vocational expertise such as in the automotive engineering programme (Lucas et al., 2012). In this context, the ChTAE should have sufficient knowledge and skills in implementing CI-STEM. The collaboration among the teacher and students are essential in order to achieve meaningful CI-STEM (Said, 2018). As mentioned by Faraday et al. (2012) that using the context that suitable with vocational school is a prominent need to teach chemistry at vocational school. Therefore, the use of CI-STEM in the vocational school is very promising. Still, the chemistry subject that taught in the high school and vocational school are different. However, many ChTAE are treat the chemistry learning activities at vocational school same as those in the high schools.

Regarding the content of chemistry at vocational school, in the automotive engineering expertise programme were potential to support the students' expertise in the automotive engineering. As an example, in the petroleum chemistry topic which can be related with the vehicle context (Wiyarsi et al., 2017). Another chemistry material that can be applied in the automotive engineering expertise are crude oil and hydrocarbons topic. From crude oil and hydrocarbons, there are contextual learning can be used relating to vehicle fuels (Febrianto \& Wiyarsi, 2018). In this case, the vocational students have to figure out chemical compound that containing in the vehicle fuel. The application of crude oil concept and hydrocarbon combustion which based on vocational context can improve students' chemistry literacy, yet not all of the students achieve chemistry literacy as good as expected (Wiyarsi et al., 2020). However, the number of chemistry teachers still have a lack of skills in integrating CI-STEM. They found difficulty in integrating STEM approach (Becker \& Park, 2011) such as in making relation among the automotive expertise and chemistry content. This condition causes chemistry teachers having a less competencies in appliance of STEM's approach in chemistry subject (Fitriyana $e t$ al., 2020). To meet this issue, the ChTAE need to master not only the knowledge about STEM but also the skills on how to design CI-STEM. The better ChTAE knowledge and skills in designing CI-STEM, the higher the chance of ChTAE to be success in applying STEM approach in chemistry subject. The good knowledge and skills of ChTAE about CI-STEM would increase teachers' self-confidence in preparing, conducting, and evaluating STEM learning (Altan \& Ercan 2016). Therefore, the purpose of this research is to investigate the chemistry teacher knowledge related STEM integration in chemistry learning at automotive engineering programme of vocational school. The research question 
used to address aforementioned problem is: How was ChTAEs'knowledge about CISTEM learning in automotive engineering vocational school?

\section{METHODS}

The methods of this research were described in this section beginning about participants and research design, data collection, and data analysis. This research employed descriptive study with survey methods. The samples consist of 19 ChTAE at automotive vocational school in Bantul Regency, Indonesia. Since all of ChTAE in Bantul were invited in the data collection activity, the samples were established through saturated sampling. Nevertheless, not all of the ChTAE were respond the data collection tools. Only 19 out of 24 ChTAE were voluntarily participated in this research. They were teaching chemistry subject for the vocational students majoring in light vehicles engineering, mechanical engineering, engineering and motorcycle business. The number of 19 ChTAE were denoted as ChT1, ChT2, ChT3, ... until ChT19. All of ChTAE were have attained Bachelor of
Education in Chemistry. However, they were different in the term of teaching experience and enrolment of teachers' professional development. The demographic data of the participants seen in Table 1.

The participants' knowledge related STEM integration in chemistry learning at vocational school were captured using STEM Knowledge Questionnaire (STEMKQ). The STEM-KQ was consisting of 9 opened questions that distributed into five aspects namely: basic knowledge concerning STEM approach, possibly of CI-STEM application in the automotive engineering vocational school, example of CI-STEM learning at vocational school, the pros and cons in using STEM approach, and appropriate chemistry learning model in implementing CI-STEM learning. This STEM-KQ were adopted following the research conducted by Fitriyana et al. (2020). The indicators distribution of STEM-KQ seen in Table 2.

The responses from ChTAE that taken from STEM-KQ instrument were analyzed using question-by-question with interpretative coding of content

Table 1

Participants' Demographic Data

\begin{tabular}{lcc}
\hline \multicolumn{1}{c}{ Parameter } & Number & $\begin{array}{c}\text { Percentage } \\
(\%)\end{array}$ \\
\hline Teaching experience & 5 & \\
Less than 5 years & 1 & 26.3 \\
5-10 years & 13 & 68.3 \\
$\quad$ More than 10 years & & \\
Teachers' Professional Development & 9 & 47.4 \\
$\quad$ Already taken & 10 & 52.6 \\
Havent't been taken & & \\
Automotive Engineering Expertise Programme & 13 & 68.4 \\
Light vehicle engineering & 5 & 26.3 \\
Mechanical engineering & 1 & 5.3 \\
Engineering and motorcycle business & & \\
\hline
\end{tabular}


Table 2

The Indicators Distribution of STEM-KQ

\begin{tabular}{|c|c|c|c|}
\hline Aspects & Indicators & $\begin{array}{l}\text { Number } \\
\text { of } \\
\text { Question }\end{array}$ & Question \\
\hline \multirow[t]{2}{*}{$\begin{array}{l}\text { Basic knowledge } \\
\text { concerning STEM } \\
\text { approach }\end{array}$} & $\begin{array}{l}\text { Describing the STEM } \\
\text { approach knowledge } \\
\text { resources }\end{array}$ & 1 & $\begin{array}{l}\text { Have you ever known STEM? } \\
\text { if you have already known it. } \\
\text { Where did you hear it? }\end{array}$ \\
\hline & $\begin{array}{l}\text { Describing the meaning of } \\
\text { STEM approach }\end{array}$ & 2 & $\begin{array}{l}\text { Give a brief description about } \\
\text { STEM according to your } \\
\text { knowledge! }\end{array}$ \\
\hline \multirow[t]{2}{*}{$\begin{array}{l}\text { Probability to apply } \\
\text { CI-STEM approach } \\
\text { in automotive } \\
\text { engineering } \\
\text { vocational school }\end{array}$} & $\begin{array}{l}\text { The relation between } \\
\text { chemistry learning and } \\
\text { vocational material in STEM } \\
\text { approach framework }\end{array}$ & 3 & $\begin{array}{l}\text { Based on your experience, } \\
\text { how was the chemistry relation } \\
\text { with vocational material in } \\
\text { the point of view of STEM } \\
\text { framework? }\end{array}$ \\
\hline & $\begin{array}{l}\text { Giving perspective } \\
\text { pertaining to the CI-STEM } \\
\text { learning in automotive } \\
\text { engineering vocational } \\
\text { school }\end{array}$ & 4 & $\begin{array}{l}\text { Do you think that STEM } \\
\text { approach can be used } \\
\text { for chemistry learning in } \\
\text { vocational school? Explicate! }\end{array}$ \\
\hline \multirow[t]{2}{*}{$\begin{array}{l}\text { The example of the } \\
\text { implementation of } \\
\text { CI-STEM learning } \\
\text { in automotive } \\
\text { engineering } \\
\text { vocational school }\end{array}$} & $\begin{array}{l}\text { Giving perspectives about } \\
\text { appropriate chemistry } \\
\text { material in automotive } \\
\text { engineering vocational } \\
\text { school that conducted using } \\
\text { STEM approach }\end{array}$ & 5 & $\begin{array}{l}\text { What is the chemistry material } \\
\text { which is appropriate to be } \\
\text { conducted using STEM } \\
\text { approach? Give us an } \\
\text { example! }\end{array}$ \\
\hline & $\begin{array}{l}\text { Explaining the examples } \\
\text { of CI-STEM learning in } \\
\text { automotive engineering } \\
\text { vocational school }\end{array}$ & 6 & $\begin{array}{l}\text { How is the chemistry learning } \\
\text { using STEM approach } \\
\text { integrated with vocational } \\
\text { material, give an example } \\
\text { about that! }\end{array}$ \\
\hline \multirow[t]{2}{*}{$\begin{array}{l}\text { The pros and } \\
\text { cons in using CI- } \\
\text { STEM learning } \\
\text { in automotive } \\
\text { engineering } \\
\text { vocational school }\end{array}$} & $\begin{array}{l}\text { Analysing the pros of } \\
\text { CI-STEM learning in } \\
\text { automotive engineering } \\
\text { vocational school }\end{array}$ & 7 & $\begin{array}{l}\text { Mention the pros of STEM } \\
\text { approach if it is applied } \\
\text { in chemistry learning at } \\
\text { automotive engineering } \\
\text { vocational schools! }\end{array}$ \\
\hline & $\begin{array}{l}\text { Analysing the cons of } \\
\text { CI-STEM learning in } \\
\text { automotive engineering } \\
\text { vocational school }\end{array}$ & 8 & $\begin{array}{l}\text { Mention the pros of STEM } \\
\text { approach if it is applied } \\
\text { in chemistry learning at } \\
\text { automotive engineering } \\
\text { vocational schools! }\end{array}$ \\
\hline $\begin{array}{l}\text { Appropriate } \\
\text { learning strategy } \\
\text { to be used in } \\
\text { STEM learning } \\
\text { at automotive } \\
\text { engineering } \\
\text { vocational school }\end{array}$ & $\begin{array}{l}\text { Explaining the appropriate } \\
\text { learning strategy to } \\
\text { implement STEM approach } \\
\text { in automotive engineering } \\
\text { vocational schools }\end{array}$ & 9 & $\begin{array}{l}\text { What learning strategy is } \\
\text { suitable with STEM approach } \\
\text { if it is applied in chemistry } \\
\text { learning at automotive } \\
\text { engineering vocational } \\
\text { schools! }\end{array}$ \\
\hline
\end{tabular}


analysis. Therefore, the ChTAE response pertaining to STEM approach in vocational school's chemistry learning were analysed following the concept of STEM learning. The question-by-question analysis means that the coding process held on each question of STEM-KQ. Thus, each analysis revealed different number of themes. The frequency and percentages of the theme on some questions were presented.

\section{FINDINGS AND DISCUSSION}

The finding of this research portrayed according to the order of opened questions on STEM-KQ. Since the STEM-KQ consists of nine questions, thus the coding process conducted toward the nine opened questions. The discussion of the findings on this research was presented along with the findings.

STEMApproach Knowledge Resources. The first question in STEM KQ "Have you ever known STEM? If you have already known it, where did you hear it?". The ChTAE response toward this question yield that all of the participants $(100 \%)$ have known the term of STEM. It means that all of the participants were familiar with the STEM approach. The resource of the participants' knowledge pertaining to STEM approach came from varied resources as seen in Table 3.

Table 3

STEM Information Source Respond

\begin{tabular}{lcc}
\hline \multicolumn{1}{c}{ Respond } & Number & Percent (\%) \\
\hline Internet & 2 & 10.53 \\
Class & 3 & 15.79 \\
Workshop & 11 & 57.89 \\
Seminar & 3 & 15.79 \\
\hline
\end{tabular}

Based on Table 3, most of participants gained STEM approach information from STEM workshop (57.89\%). Those workshops were the partnership held between Yogyakarta government and Education University in Indonesia. Instead of the partnership, there was also 'MGMP' as a chemistry vocational teacher' group activity that regularly conducting workshop about STEM. The MGMP aims to increase STEM approach competence of vocational school chemistry teachers. Therefore, as they finish their workshop, they will be able to increase and develop knowledge about STEM approach. As in research conducted by Shernoff et al. (2017) which states that some of the STEM teachers need STEM training so they can perceive the STEM concept and STEM integration examples better. Another research defines that STEM approach can improve the chemistry teacher candidate (Gunbatar et al., 2018). Therefore, the Indonesian government were supported the implementation of CI-STEM learning.

Instead of the previous statements, the ChTAE also receives STEM knowledge from some resources, those are when they were enrolled in a class (15.79\%), following seminar $(15.79 \%)$, and from the internet $(10.53 \%)$. It was signifying that ChTAE have curiosity in pertaining to STEM approach. Therefore, ChTAE usually try to find about STEM knowledge source from many activities that they can find.

The Meaning of STEM Approach. Second question that asked to the ChTAE was "Give a brief description about STEM according to your knowledge!". The perceiving response received from the participants indicated that most of the participants $(94.70 \%)$ assume that STEM approach is Science, Technology, Engineering, and Mathematics learning integration. As an example of the original answer from ChT14, "STEM learning is integrated learning between Science, Technology, Engineering, and Mathematic aiming to improve problem solving's learner's activity". 
The majority participants statements were in line with Banks and Barlex (2014) also Felder and Brent (2016) who stated implicitly that STEM education is Science, Technology, Engineering, and Mathematics that used by teachers/students to solve a problem. This is also confirmed the works of Kelley and Knowles (2016) which stated that STEM education basically is an approach used to teach STEM content consisting two or more STEM subjects. In another perspectives, the STEM approach allows the students to think independently.

The high percentage of the responses given by the respondent suiting with STEM approach definition signifies that ChTAE at vocational school have an intact understanding of STEM approach definition. It was because the participants have figured out STEM approach information from many sources as seen in Table 3 . The findings confirmed the previous research held by Fitriyana et al. (2021) and Nugroho et al. (2019) that half of the teachers joining STEM workshop bring the increasing skills in preparing CI-STEM.

The Relation Between Chemistry Learning and Vocational Material in STEM Approach Framework. The third question "Based on your experience, how was the chemistry relation with vocational material in the point of view of STEM framework?". A total of $63.20 \%$ of research participants stated that chemistry content was supported the vocational expertise in STEM approach framework. As an example, the response of the ChT7 as follows: "Some of chemistry material will be much useful to support learners majoring in automotive".

The relevance of chemistry content with the automotive engineering context was linked by the use of context-based learning (Magwilang, 2016). The research conducted by Wiyarsi, Pratomo et al. (2020) stated that context-based learning brings the students to be able to connect the chemistry content with the vocational context i.e., the crude oil learning with vehicles problem context in the automotive engineering expertise programme of vocational school.

On the other hand, a total of $37.80 \%$ of the participants mentioned that the chemistry material can be integrated with vocational context using STEM approach. The ChT11 described that: "Chemistry material can be integrated with STEM approach in vocational learning".

Liu et al. (2014) stated that integrated STEM approach in vocational school can improve students' self-confidence. This is in line with Banks and Barlex (2014) who have the common perspective that the integrated STEM learning could support the competencies of the student at vocational school.

Perspective of CI-STEM Learning in Automotive Engineering Vocational School. The fourth question "Do you think that STEM approach can be used for chemistry learning in vocational school? Explicate!'. All of the participants response that STEM approach can be used in chemistry learning at automotive engineering vocational school. There were $42.11 \%$ of participants explained that STEM can be used in chemistry learning at automotive engineering expertise programme of vocational school because STEM approach can assist the students to apply chemistry material along with the context of automotive engineering.

The findings of this research confirmed the preceding research conducted by Sari et al. (2018) that the engagement of vocational students in a project accomplishment can be triggered by the implementation of STEM. In addition, there were $21.05 \%$ of the participants stating that STEM approach can be used in this case because STEM 
can adjust the students to accomplish daily life problems relating with chemistry and automotive engineering. This is in line with Gullen (2019) that the integration of STEM approach brings the increasing of the skills that deal with daily life problem solving. Also, there were $21.05 \%$ of the participants declared that STEM approach was suitable with automotive engineering of chemistry learning however not for all of the chemistry. Still, a total of $15.79 \%$ of the participants did not gave clear perspective about their opinions. It means that the participants still need to upgrade their knowledge and skills about STEM in chemistry learning at automotive engineering vocational school.

Perspectives About Appropriate Chemistry Topic in Automotive Engineering Vocational School That Conducted Using STEM Approach. The fifth questions "What is the chemistry topic which is appropriate to be conducted using STEM approach? Give us an example!". The responses of 19 participants yield 31 answers that categorized into seven chemistry material (see Table 4).

Based on the data in Table 4, most of the participants agreed that the substance characteristics was the most appropriate chemistry topic to be integrated using STEM learning. The electrochemistry topic was another topic that was suitable to be implemented using STEM. Only a total of $26.32 \%$ of the participants that can mentioned the example of chemistry learning in certain topic using STEM. The participant gives an example about the application of electrochemistry topic by giving a project to the students to make electricity kit using fruits or another plant that can be found in their house. Another participant mentioned that the STEM learning can be experienced by asking the student to make simple motorcycle accumulator or electric vehicle battery. Related with the topic of substance characteristics, the CI-STEM learning can be conducted by asking the students to make natural $\mathrm{pH}$ indicator, ice cream, jelly, and dalgona coffee. Still, related with the hydrocarbon topic, asking the students to make hydrocarbons model of molecular shape geometry could be an option.

The Examples of CI-STEM Learning in Automotive Engineering Vocational School. The sixth question "How is the chemistry learning using STEM approach integrated with vocational material, give an example about that!'. The participants' response towards this question signified that only $36.84 \%$ of the participants have been applied STEM approach in chemistry learning

Table 4

Chemistry Topic Integrated with Stem in SMK

Automotive Engineering

\begin{tabular}{lcc}
\hline \multicolumn{1}{c}{ Chemistry Topic } & $\begin{array}{c}\text { Answer } \\
\text { Frequency }\end{array}$ & $\begin{array}{c}\text { Percentage } \\
(\%)\end{array}$ \\
\hline Substance mixture separation & 3 & 9.68 \\
Chemical reaction & 2 & 6.45 \\
Stoichiometry & 2 & 6.45 \\
Substance characteristic & 11 & 35.48 \\
Reduction oxidation reaction & 4 & 9.68 \\
Electrochemistry & 5 & 16.13 \\
Hydrocarbons & 4 & 9.68 \\
\hline
\end{tabular}


at automotive engineering vocational school. It means that the ChTAE have little experiences in applying STEM approach in chemistry learning. The participants" answers were categorizes into 3 themes. A number of $14.79 \%$ of the participants agreed that chemistry learning integrated with STEM could support learning material in vocational automotive engineering. A total of $15.79 \%$ participants stated that chemistry learning integrated with STEM was linked the chemistry material with automotive engineering vocational school. In addition, as many as $5.26 \%$ of the participants said that chemistry learning integrated with STEM could help the students to solve daily life problems along with their expertise. However, the example of STEM implementation given by several participants (ChT6, ChT8, and ChT13) were not suitable with the automotive engineering expertise (see Table 5). That incongruity implicitly shows that ChTAE have lack of competence in applying STEM in chemistry learning according to specific major. Therefore, the research participants need to improve their skills and experiences in applying STEM approach.
The Cons of CI-STEM Learning in Automotive Engineering Vocational SchoolI. Question number 7 "Mention the pros of STEM approach if it is applied in chemistry learning at automotive engineering vocational schools!". The participants response toward this question were categorized into 5 themes as seen in Table 6. From the Table 6, a total of $94.74 \%$ of participants explain the cons of the implementation of STEM in chemistry learning at automotive engineering vocational school. Most of the participants assumed that STEM approach can't be applied in all of the chemistry material in automotive engineering vocational school. This finding is in-line with Fitriyana et al. (2020) that describing not all of the chemistry topics can be taught using STEM. Another participant response that application of STEM in chemistry learning in automotive engineering vocational school takes a time. In line with the previous statement, Sheffield et al. (2018) explained that STEM approach implementation in Indonesia constrained by the limitation of time, teacher competencies, and the chemistry curricula density. Overall, the cons of the use of STEM mentioned by participants

Table 5

ChTAE Experience in Implementing STEM Approach

\begin{tabular}{ll}
$\begin{array}{c}\text { Research } \\
\text { Participant }\end{array}$ & \multicolumn{1}{c}{ Implementation of STEM Approach } \\
\hline ChT1 & $\begin{array}{l}\text { Learning about motor vehicle batteries on electrochemical } \\
\text { materials } \\
\text { ChT2 }\end{array}$ \\
& $\begin{array}{l}\text { Learning about motor vehicle fuel on the material of } \\
\text { hydrocarbon compounds }\end{array}$ \\
ChT3 & Learning about octane number in petroleum material \\
ChT5 & Coating of anti-rust agent on vehicle frame on redox material \\
ChT8 & Making virgin coconut oil \\
ChT6 & Chemical batik making on hydrocarbon compounds \\
ChT13 & Making water quality test tool in fisheries learning \\
\hline
\end{tabular}


Table 6

The Cons of Chemistry Integrated STEM Learning in Automotive Vocational School

\begin{tabular}{lcc}
\multicolumn{1}{c}{ The Cons of STEM Learning } & $\begin{array}{c}\text { Answer } \\
\text { Frequency }\end{array}$ & $\begin{array}{c}\text { Percentage } \\
(\%)\end{array}$ \\
\hline $\begin{array}{l}\text { STEM approach can't be applied to all of chemistry } \\
\text { material in automotive engineering vocational school }\end{array}$ & 7 & 38.84 \\
$\begin{array}{l}\text { Students of automotive engineering vocational school are } \\
\text { lack of competencies in conducting chemistry learning }\end{array}$ & 3 & 15.79 \\
$\begin{array}{l}\text { integrated with STEM } \\
\begin{array}{l}\text { The implementation of STEM approach application in } \\
\text { chemistry learning at vocational school takes long }\end{array}\end{array}$ & 5 & 26.32 \\
$\begin{array}{l}\text { Vocational school facilities are still deficient and unable } \\
\text { to support chemistry learning integrated with STEM } \\
\text { n/A }\end{array}$ & 3 & 15.79 \\
\hline
\end{tabular}

caused by the teachers' difficulty to connect the congruity between chemistry content with automotive engineering expertise that basically aims to increase students' skills.

The Pros of CI-STEM Learning in Automotive Engineering Vocational School. Instead of the cons of the implementation of STEM, the participants also gave response about the pros of the implementation of STEM approach in chemistry learning at automotive engineering vocational school. The question that given was "Mention the pros of STEM approach if it is applied in chemistry learning at automotive engineering vocational schools!". A total of $94.74 \%$ participants gave their view on the STEM implementation in chemistry learning at automotive engineering vocational school. Those responses can be seen in Table 7. Most of participants' response that students were more satisfied toward the chemistry learning using

Table 7

The Pros of STEM Approach Application in Chemistry Learning at Automotive Engineering Vocational School

\begin{tabular}{lcc}
\hline \multicolumn{1}{c}{ The Pros of STEM learning } & $\begin{array}{c}\text { Answer } \\
\text { Frequency }\end{array}$ & $\begin{array}{c}\text { Percentage } \\
\text { (\%) }\end{array}$ \\
\hline Improving students' skills & 2 & 10.53 \\
Improving students' creativity & 2 & 10.53 \\
Helping students to solve daily life problems & 3 & 15.79 \\
Provide more meaningful and interesting chemistry & 6 & 31.58 \\
learning & & \\
Helping students to solve complex chemistry problem & 2 & 10.53 \\
Helping students to study integrated chemistry learning & 2 & 10.53 \\
in automotive engineering vocational school. & & \\
Improving students' critical thinking & 1 & 5.26 \\
n/A & 1 & 5.26 \\
\hline
\end{tabular}


STEM approach because it transforms the learning activities more enjoyable and interesting. The finding of this study in line with the varied studies that STEM approach enhances the students' creativity, knowledge, motivation, interest, career, and self-confident (Lou et al., 2017; Liu et al., 2014; Shahali et al., 2016; Susanti et al., 2018). In addition, Hinze et al. (2013) also identified that chemistry learning integrated with STEM could increase the visual ability of the students therefore it improves students' understanding toward the abstract chemistry material.

Appropriate Learning Strategy to Implement STEM Approach in Automotive Engineering Vocational Schools. The last question on STEM-KQ "What learning strategy is suitable with STEM approach if it is applied in chemistry learning at automotive engineering vocational schools?". The responses given by the participants in correspond to this question are varied (see Table 8). Most of the research participants stated that Project Based Learning (PjBL) and Problem based Learning (PBL) is the two most appropriate model in this context (Banks \& Arlex, 2014; Shelley \& Kiray, 2018).

The PjBL involves students in an authentic learning because they were enrolled in a project-based assignment (Tan \& Chapman, 2016). In PjBL, the students receive knowledge and skills. The students also play an important role in investigating opened question to make the conveyance of their understanding directing to their goal (Kraus \& Boss, 2013). Through the use of $\mathrm{PjBL}$, it allows the student to acquire meaningful new knowledge (Baptist et al., 2020). Therefore, the implementation of PjBL model integrated with STEM could assist the students to provide authentic and contextual experience (Capraro et al., 2013). PjBL integrated with STEM requires the students to have analytical and critical thinking thus it will improve their higher order thinking skills. Lou et al. (2017) also found that $\mathrm{PjBL}$ integrated with STEM learning may improve students' creativity, knowledge, and motivation. Another study signified that $\mathrm{PjBL}$ integrated with STEM is very important and effective in triggering students' motivation and understanding about the content taught (Han et al., 2015). PjBL integrated with STEM is built based on engineering technique as the fundamental background and supported by the foundation of science, technology, and mathematics to solve the real-world problem. Instead of PjBL model and PBL model, few of participants mentioned that discovery learning, scientific approach, demonstration and experiment methods were also suitable in supporting the implementation of STEM.

Table 8

Learning Strategy Suiting with STEM Approach

\begin{tabular}{lcc}
\hline \multicolumn{1}{c}{ Learning Strategy } & $\begin{array}{c}\text { Answer } \\
\text { Frequency }\end{array}$ & $\begin{array}{c}\text { Percentage } \\
(\%)\end{array}$ \\
\hline Problem Based Learning Model & 7 & 36.84 \\
Project Based Learning Model & 8 & 38.1 \\
Discovery Learning Model & 2 & 9.52 \\
Scientific Approach & 2 & 9.52 \\
Demonstration Methods & 1 & 4.76 \\
Experiment Methods & 1 & 4.76 \\
\hline
\end{tabular}




\section{CONCLUSION AND IMPLICATION}

The findings of this research signified that most of ChTAE have basic knowledge of integrated STEM learning such as describing the definition and framework of STEM, giving example of STEM based learning at certain chemistry topic, explaining the cons and pros of the STEM based learning and also highlighting appropriate strategy to implement CI-STEM at automotive engineering vocational school. However, the ChTAE still deficient in giving examples about chemistry learning material that can be integrated with STEM approach. Instead of that, there is ChTAE that still found difficulties in determining the STEM that appropriate with chemistry topic at automotive engineering vocational school. Therefore, it is suggested to improve pre-service chemistry teachers' skills in preparing and designing CI-STEM learning at vocational school when they were still enrolled in the teacher preparation degree.

\section{REFERENCE}

Altan, E. B., \& Ercan, S. (2016). STEM education program for science teachers: perceptions and competencies. Journal of Turkish Science Education, 13, 103-117. https://doi.org/10.12973/ tused.10174a.

Banks, F., \& Barlex, D. (2014). Teaching stem in secondary school helping teachers meet the challenge. Routledge Taylor \& Francis Group.

Baptist, K. J., Utami, D. N., Subali, B., \& Aloyius, S. (2020). Effectiveness of project-based learning and 5E learning cycle instructional models. Jurnal Kependidikan, 4(1), 55-69. https:// journal.uny.ac.id/index.php/jk/article/ view/27107/pdf.

Becker, K., \& Park, K. (2011). Effects of integrative approaches among science, technology, engineering, and mathematics (STEM)subjects on students' learning: A preliminary meta-analysis. Journal of STEM Education, 12 (5\&6), 23-37. https:// doi.org/10.29333/iejme/5885.

Capraro, R. M., Capraro, M. M., \& Morgan, J. R. (2013). STEM project-based learning an integrated science, technology, engineering, and mathematics (STEM) approach. Sense Publishers.

Charismiadji, I. (2015, November 23). Pendidikan berbasis STEM jawaban tantangan global. Berita Satu. https:// www.beritasatu.com/kesra/324186/ pendidikan-berbasis-stem-jawabantantangan-global

Faraday, S., Overton, C., \& Cooper, S. (2011). Efective teaching and learning in vocational school. LSN.

Febrianto, \& Wiyarsi, A. (2018). Bahan ajar kimia hidrokarbon dan minyak bumi untuk sekolah menengah kejuruan (SMK) teknik otomotif. UNY Press.

Felder, R. M., \& Brent, R. (2016). Teaching and learning STEM a practical guide. Jossey-Bass A Wiley Brand.

Fitriyana, N., Wiyarsi, A., Pratomo, H., Marfuatun, Krisdiyanti, A., \& Adilaregina, W. (2020). In-service chemistry teachers' prior knowledge regarding STEM integration in high school chemistry learning. Advances in Social Science, Education and Humanities Research, 528, 218 230. https://dx.doi.org/10.2991/ assehr.k.210305.033

Gullen, S. (2019). The effect of STEM education roles on the solution of daily life problems. Participatory Educational Research, 6(2), 37-50. https://doi.org/10.17275/per.19.11.6.2

Gunbatar, S. A, Celikkiran, A.T, Kutucu, E. S., \& Kiran, B. E. (2018). The 
influence of a design-based elective STEM course on pre-service chemistry teachers' content knowledge, STEM conceptions, and engineering views. Chemistry Education Research and Practice, 19(3), 954-972. https://doi. org/10.1039/C8RP00128F.

Gunbatar, S. A. (2020). Making homemade indicator and strips: A STEM + activity for acid-base chemistry with entrepreneurship applications. Projects and Curriculum Ideas in STEM Classrooms, 57(3), 132-141. https://doi.org/10.1080/00368121.20 20.1828794

Han, S., Yalvac, B., Capraro, M. M., \& Capraro, R. M. (2015). In-service teachers' implementation and understanding of STEM projectbased learning. Eurasia Journal of Mathematics, Science \& Technology Education, 11(1), 63-76. https://doi. org/10.12973/eurasia.2015.1306a

Hinze, S. R., Rapp, D. N., Williamson, V. M., Shultz, M. J., Deslongchamps, G., \& Williamson, K. C. (2013). Beyond ball-and-stick: Students' processing of novel STEM visualizations. Learning and Instruction, 26, 1221. https://doi.org/10.1016/j. learninstruc.2012.12.002.

Kelley, T. R., \& Knowles, G. (2016). A conceptual framework for integrated STEM education. International Journal of STEM Education, 3(11), 1-11. https://doi.org/10.1186/s40594016-0046-z.

Kraus, J., \& Boss, S. (2013). Thinking through project-based learning guiding deeper inquiry. Corwin.

Liu, Y. H., Lou, S. J., \& Shih, R. C. (2014). The investigation of STEM selfefficacy and professional commitment to engineering among female high school students. South African Journal of Education, 34(2), 1-15. https://hdl. handle.net/10520/EJC153692.

Lou, S. J., Chiu, Y. C., Shih, R. C., \& Chung, C. C. (2017). A study creativity in $\mathrm{CaC}_{2}$ steamship-derived stem project-based learning. EURASIA Journal of Mathematics Science and Technology Education, 13(6), 2387-2404. https://doi.org/10.12973/ eurasia.2017.01231a.

Lucas, B., Spencer, E., \& Claxton, G. (2012). How to teach vocational education: A theory of vocational pedagogy. City \& Guilds Centre for Skills Development.

Magwilang, E. B. (2016). Teaching chemistry in context: Its effects on students' motivation, attitudes and achievement in chemistry. International Journal of Learning, Teaching and Educational Research, 15(4), 60-68. https://www.ijlter.org/ index.php/ijlter/article/view/670.

National Research Council. (2011). Successful K-12 STEM education. The National Academies Press.

Nugroho, O. F., Permanasari, A., \& Firman, H. (2019). The movement of STEM education in Indonesia: Science teachers' perspectives. Journal of Indonesian Science Education, 8(3), 417-425. https://doi.org/10.15294/jpii. v8i3.19252.

Pilz, M., Berger, S., \& Canning, R. (2012). Fit for business pre-vocational education in european Schools. Springer VS.

Said, A. (2018). Vocational teachinglearning through the eyes of undergraduate vocational students in Malta: A qualitative exploratory study. International Journal for Research in Vocational Education and Training (IJRVET), 5(1), 42-63. https://doi. org/10.13152/IJRVET.5.1.3. 
Sari, R. P., Adlim, M., \& Gani, A. (2018). STEM learning in regular and vocational high schools on the topic of scientific menu card fabrication. IOP Conf. Series: Journal of Physics: Conf. Series, 1088, 012112. https://doi.org/10.1088/17426596/1088/1/012112.

Shahali, E. H. M., Halim, L., Rasul, M. S., \& Osman, K. (2016). STEM learning through engineering design: Impact on middle secondary student's interest towards STEM. EURASIA Journal of Mathematics Science and Technology Education, 13(5), 1189-1211. https://doi.org/10.12973/ eurasia.2017.00667a.

Sheffield, R., Koul, R., Blackley, S., Fitriani, E., Rahmawati, Y., \& Resek, D. (2018). Transnational examination of STEM education. International Journal of Innovation in Science and Mathematics Education, 26(8), 67-80.

Shelley, M., \& Kiray, S. A. (2018). Research highlights in STEM education. ISRES Publishing.

Shernoff, D. J., Sinha, S., Bressler, D. M., \& Ginsburg, L. (2017). Assessing teacher education and professional development needs for the implementation of integrated approaches to STEM education. International Journal of STEM Education, 4(1), 1-16. https://doi. org/10.1186/s40594-017-0068-1.

Susanti, L. Y., Hasanah, R., \& Khirzin, M. H. (2018). Penerapan media pembelajaran berbasis Science, Technology, Engineering, and Mathematics (STEM) untuk meningkatkan hasil belajar siswa SMA/SMK pada materi reaksi redoks. Jurnal Pendidikan Sains, 6, 32-40. https://doi.org/10.26714/ jps.6.2.2018.32-40.

Tan, J. C. L., \& Champan,A. (2016). Projectbased learning for academically-able students. Sense Publishers.

Wang, H. H., Moore, T. J., Roehrig, G. H., \& Park, M. S. (2011). STEM integration: Teacher perceptions and practice. Journal of Pre-College Engineering Education Research, 1(2), 1-13. https:// doi.org/10.5703/1288284314636.

Wiyarsi, A., Damanhuri, M. I. M., \& Fitriyana, N. (2020). Exploring preservice chemistry teachers' problemsolving skills on vocational contextbased learning. Jurnal Kependidikan, 4(2), 185-199. https://journal.uny.ac.id/ index.php/jk/article/view/35302/pdf.

Wiyarsi, A., Pratomo, H., \& Priyambodo, E. (2017). Chemistry learning: perception and interest of vocational high school students of automotive engineering program. Conference: International Seminar on Science Education (3 ${ }^{\text {th }}$ ISSE), 3, 2476-9533.

Wiyarsi, A., Pratomo, H., \& Priyambodo, E. (2020). Vocational high school students' chemical literacy on contextbased learning: A case of petroleum topic. Journal of Turkish Science Education, 17(1), 147-161. https://doi. org/10.36681/tused.2020.18. 